\title{
Terrestrial groundwater and nutrient discharge along the 240-km-long Aquitanian coast
}

\author{
Pierre Anschutz*, Céline Charbonnier, Jonathan Deborde, Loris Deirmendjian, Dominique Poirier, \\ Aurélia Mouret ${ }^{1}$, Damien Buquet, Pascal Lecroart
}

Université de Bordeaux, CNRS, UMR 5805 Environnements Paléoenvironnements Océaniques et Continentaux (EPOC), 33615 Pessac, France

\section{A R T I C L E I N F O}

\section{Article history:}

Received 6 October 2015

Received in revised form 10 February 2016

Accepted 6 April 2016

Available online 9 April 2016

\section{Keywords:}

Submarine groundwater discharge

Nutrient

Coastal dune

Subterranean estuary

\begin{abstract}
A B S T R A C T
We collected samples from sea water, runnel water, beach pore waters, water from the unconfined surficial aquifer discharging at the beach face, groundwater, and rainwater from the Aquitanian coast in order to determine the flux of dissolved inorganic nitrogen (DIN), phosphorus and silica from terrestrial submarine groundwater discharge (SGD). The flux of fresh groundwater was obtained from a water balance calculation based on precipitation and evapotranspiration and assessment of the coastal watershed from hydrograph separation. Waters with intermediate salinities between sea water and freshwaters are found all along the $240-\mathrm{km}$-long coast, indicating that SGD is ubiquitous. The estimated fresh water flux is $2.25 \mathrm{~m}^{3} \mathrm{~d}^{-1} \mathrm{~m}^{-1}$ longshore. Terrestrial SGD provides a DIN flux of $9 \cdot 10^{6} \mathrm{~mol}$ each year to the adjacent coastal zone. This flux is about four times lower than the release of DIN due to tidally driven saline SGD. The freshwater DIN flux is low because the upland land use consists almost exclusively of pine forest. Dissolved organic nitrogen represents more than $60 \%$ of the total dissolved nitrogen flux. Dissolved iron, phosphorus and silica have much higher concentrations in the anoxic forest aquifer than in the fresh-water end-member of the subterranean estuary sampled in the upper beach aquifer. This suggests that the salinity gradient of the estuary does not correspond to a redox gradient. The redox front between anoxic groundwater and fresh oxic waters occurs below the soil-depleted foredune/yellow dune. Anoxic P- and Si-rich waters seep directly on the beach face only in the north Gironde, where the foredunes are eroded. This study reveals the role of the sandy foredune aquifer in biogeochemical fluxes from SGD, which is to dilute and oxidize waters from the unconfined surficial upland aquifer.
\end{abstract}

(c) 2016 Elsevier B.V. All rights reserved.

\section{Introduction}

Submarine Groundwater Discharge (SGD) plays a significant role in freshwater and biogeochemical fluxes of some coastal zones (Moore, 2010) and the global ocean (Kwon et al., 2014). Direct SGD might be responsible for up to $10 \%$ of the total terrestrial water input to estuaries and to the ocean (Garrels and MacKenzie, 1971). It may represent $2400 \mathrm{~km}^{3} \mathrm{y}^{-1}$ (Zektser and Loaiciga, 1993) compared to total runoff, which is estimated at $37,400 \mathrm{~km}^{3} \mathrm{y}^{-1}$ (Berner and Berner, 1987).

The world's coastlines are dominated by sandy shores (McLachlan and Brown, 2006). The intertidal zone of permeable sandy sediments represents an environment where nutrient dynamics is governed by diagenitic recycling of biogenic compounds (e.g. Billerbeck et al., 2006), recirculation of pore waters (Deborde et al., 2008; Anschutz et al., 2009), or seepage of terrestrial groundwaters (e.g. Ullman et al., 2003; Charette and Sholkovitz, 2002). Seepage of terrestrial

\footnotetext{
* Corresponding author.

E-mail address: pierre.anschutz@u-bordeaux.fr (P. Anschutz).

1 Present address: UMR-CNRS 6112 Université d'Angers LPG-BIAF 49045 Angers, France.
}

groundwater through coastal permeable sediments occurs where aquifers have a positive head relative to sea level; almost all coastal zones are subject to such flow (Burnett et al., 2006). Therefore, freshwater discharge through coastal sandy sediments has been recognized as a widespread phenomenon. Fluid circulation in tidal permeable sediment has received increasing attention due to its potential importance in the transport of chemical constituents to the sea. Freshwater inputs have effects on the carbon and nutrient cycles (Kroeger and Charette, 2008; Spiteri et al., 2008; Bowen et al., 2007), but estimated fluxes of terrestrial groundwater are highly variable and quantification remains problematic. That is why very few data exist on the direct contribution of groundwater to nutrient input to coastal zones. On a local scale, groundwater-borne nutrient loads may be important in maintaining primary production (Zimmermann et al., 1985; Lee et al., 2010). But when coastal pore water is mixed with terrestrial groundwater, it becomes difficult to determine the proportion of nutrient input caused by in situ mineralization of organic matter (e.g. Charbonnier et al., 2013a) and that originating from freshwater seepage.

Different approaches have been used to improve estimates of groundwater flow and nutrient load to coastal ocean (Burnett et al., 2006). Groundwater temperature can be used to estimate groundwater 
discharge rates. A temperature difference in the groundwater-surfacewater system is a qualitative signal of groundwater seepage that can be detected using remote sensing infrared signal (Fischer et al., 1964; Lévêque et al., 1972; Roxburgh, 1985; Banks et al., 1996). The use of remote sensing technologies to quantify groundwater seepage requires intensive field calibration, which has never been performed. Seepage meters are a direct technique that can be used in a relatively calm environment (Taniguchi and Fukuo, 1993). Recent developments of radium and radon isotopic techniques have permitted evaluations of groundwater flows at local, regional, and global scales (Moore, 2010; Kwon et al., 2014). These techniques may discriminate terrestrial water seepage fluxes from recirculating sea water in permeable marine sediments. Radium and radon are commonly used as tracers of saline and total SGD, respectively. The difference between them is the fresh part (Knee and Paytan, 2011). But radon is subject to exchange with the atmosphere, which may be difficult to model under some circumstances (e.g., waves breaking along a shoreline). Another approach is the water balance calculation. This approach simply links the terrestrial aquifer with the beach through the discharge of groundwater, which is set by precipitation, evapotranspiration, runoff, and groundwater pumping over an extended period in the catchment area that drains the coastal zone directly. Estimates of nutrient load obtained from this approach may be based on measured nutrient concentrations from upland monitoring wells. However, groundwater nutrient concentrations are generally transient because of biologically and chemically mediated reactions (e.g., Ullman et al., 2003; Slomp and Van Cappellen, 2004; Kroeger and Charette, 2008; Santos et al., 2008). To account for such non-conservative behaviour in an aquifer, groundwater load estimates can be based on nutrient concentrations measured at the seepage zone (Charette et al., 2001; Michael et al., 2003; Loveless and Oldham, 2010).

Discharging groundwater flux and its nutrient contribution are much easier to estimate in regions where fluids may seep into a body of water having limited circulation, such as a semi-enclosed basin. Identification of terrestrial groundwater nutrient flux on an open ocean reflective beach with tidal currents and breaking waves remains a challenge. The $240-\mathrm{km}$-long Aquitanian coast is a sandy coast where nutrient recycling due to sea water circulation and tidal pumping has been recognized from the study of saline $(S>34)$ interstitial and seeping waters (Anschutz et al., 2009; Charbonnier et al., 2013a). Organic matter supplied by the sea water entering the pore spaces during floods is trapped long enough to be mineralized. This efficient recycling process supplies 600 tonnes of $\mathrm{N}$-nitrate to the adjacent coastal zone annually. These studies also showed that some brackish waters could be sampled on the beach at low tide, suggesting that terrestrial water seepage occurred. To study the impacts of terrestrial groundwater on a largescale high-energy coastal environment, we have made an estimate of the quantity of nutrients that are discharged to the coastal zone of the Aquitanian beach using a water balance calculation and spatial monitoring of groundwater in upland wells and seeping on the beach at low tide.

\section{Material and methods}

\subsection{Study site}

The French Aquitanian coast forms a vast unique natural environment in Western Europe. This relatively protected milieu is a $240-\mathrm{km}-$ long straight coast bordered by Aeolian dunes several tens of metres high and exposed to high-energy conditions in a meso-macrotidal setting. This coast is located between the Gironde and Adour estuaries (Fig. 1) and is interrupted by the Arcachon lagoon tidal inlet, which is approximately $5 \mathrm{~km}$ wide. The tide is of meso-macro type, with an average tidal range of $3.2 \mathrm{~m}$, extending up to $5 \mathrm{~m}$ during spring tides. The Aquitanian coast commonly displays double bar beaches with very dynamic rhythmic features, such as the presence of ridge and runnel systems developed more or less in relation with meteorological conditions (Michel and Howa, 1999; Castelle et al., 2007). The coast is exposed to high energy North Atlantic swells travelling mainly from the W-NW sector (Butel et al., 2002). Beaches are mainly intermediate double-barred following the classification of Short (1991) and Short and Aagaard (1993).

A morphological analysis has subdivided the Aquitanian coast from north to south into two main groups with homogeneous dynamic behaviour: the coast north of the Arcachon bay with gentle slope beaches, which are subjected to erosion in the northernmost part; and the more stable coast south of the Arcachon bay, with beaches increasingly inclined toward the south. The beaches between the Verdon and Montalivet are in erosion. There, the beaches are flat and limited by cliffs made of Pleistocene cemented sands and palaeosoils. Terrestrial groundwater seeps directly out of the cliffs at the sand palaeosoils limit.

The beach catchment, that is, the land area that is not drained by a river or lakes and that is directly connected to the beach, has been delimited using the Geographic Information System (GIS) ArcGIS. It represents a 0 to $10 \mathrm{~km}$ wide strip of land along the coastlines, which covers $822 \mathrm{~km}^{2}$. The coastal aquifer, composed of sand dunes, marine sands, and gravels of Plio-Quaternary period, is very permeable (Legigan, 1979). Foredune and cultivated pine forests located behind the foredune on Holocene dunes represent more than $90 \%$ of the total surface of the catchment area. Housing is confined to a few spots of the coastal zone.

The mean precipitation in the middle part of the studied beach at Cap Ferret was $810 \mathrm{~mm} \mathrm{y}^{-1}$ between 1967 and 2014. In recent years, the values were $542,744,936$, and $899 \mathrm{~mm}$ in 2011, 2012, 2013, and 2014 respectively, showing the large heterogeneity. The amount of water supplied by rainfall was compared to the stream flow in the neighbouring watershed of the Leyre river (Canton et al., 2012) so that an evaporation rate could be defined. The evaporation rate was between 40 and $80 \%$, which is typical of a forested catchment (Bosch and Hewlett, 1982; Vertessy et al., 2003). The direct measurement of evapotranspiration in the dune forest located in the studied area gave a value of 51\% (Pitaud, 1967), but this value was obtained from the measurements of transpiration of young pines during one year. It did not take into account the understory cover. A recent modelling approach that considered all the hydrological parameters and land covers indicated that evapotranspiration fluxes in pine forest of the Aquitanian coastal region were in the range of 234 to $570 \mathrm{~mm} \mathrm{y}^{-1}$ (Govind et al., 2014), which represented 30 to $70 \%$ of the mean annual precipitation. Low values were obtained for young stands whereas high values were obtained for mature pine forest. The dune forest consists mostly of mature forest, suggesting that evapotranspiration represented close to $70 \%$ of precipitation. The excess rainfall would go to either surface runoff or groundwater recharge. In the case of the Aquitanian coastal watershed, surface runoff does not exist and we consider that the excess water feeds the aquifer.

\subsection{Sampling}

Several kinds of water samples were collected, including sea water, runnel water, beach pore waters, water from the unconfined surficial aquifer discharging at the beach face, groundwater, and rainwater (Fig. 2). Runnel waters are those sampled in large pools isolated at low tide on the lower beach. Water samples of the intertidal zone were collected at low tide in winter and spring 2007, 2008, and 2009 at several places accessible by car along the Aquitanian coast (Fig. 1) and during several periods between 2011 and 2013 on Truc Vert Beach. Samples were collected during periods of spring tide. Truc Vert beach is located a few kilometres north of the Cap Ferret sand spit (Fig. 1). It is representative of the Aquitanian coast and protected from human disturbance by difficult access. The boundary between the unsaturated and saturated zones defines the water table. The intersection of the water table and the beach face defines the seepage zone. 


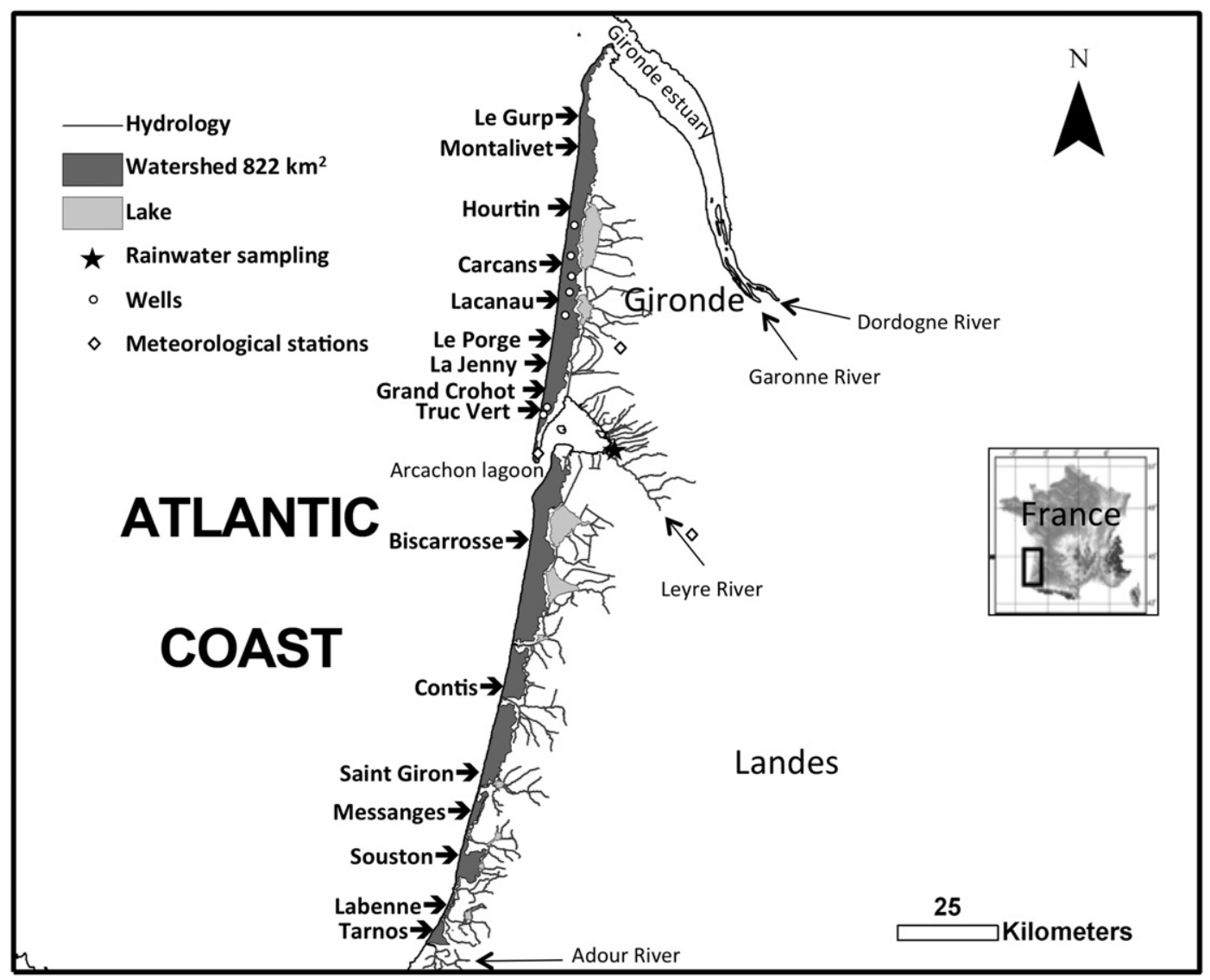

Fig. 1. Sampling site location. Arrows indicate beaches where pore waters were sampled at low tide. The beach watershed was determined from hydrograph separation.

Pore waters were sampled in the saturated zone of the beach, where sediment pores were filled by interstitial water. To collect interstitial and seeping waters on the beach, we bored several holes at low tide along cross-shore transects, until the borehole reached the saturated zone in the intertidal sandy beach. Pore waters were reached at the surface on the lower beach and down to $2 \mathrm{~m}$ depth on the upper beach. The first water that filled the bottom of the hole was removed with a polypropylene beaker. Due to the high permeability of sand, the hole refilled immediately and the measurements of temperature and salinity and the sampling were performed on this water. Waters were immediately subsampled using a 50-mL syringe and filtered through a $0.45 \mu \mathrm{m}$ cellulose acetate syringe-membrane. Sea water and runnel water were sampled directly with a 50-mL syringe.

Three 7-m-long piezometers were put on the upper Truc Vert beach in February 2013, between the high spring tide level and the dune.
Installation of piezometers in the tidal beach section was ruled out because of high-energy conditions. Oxygen concentration and temperature were recorded with Aanderaa 3835 optodes equipped with NKE data loggers located at the bottom of each piezometer. These probes achieved a precision of $\pm 5 \%$ for oxygen without consumption (optical measurement) or significant drift. The oxygen probes were tested in the laboratory before and after each field deployment. Samples were collected in February-March 2013 and in September-October 2013 every day during one lunar cycle. Three Tygon tubes with an inner diameter of $5 \mathrm{~mm}$ were firmly fixed in each well at different depths in order to avoid disturbance and to obtain a vertical distribution of parameters. Samples were brought to the surface through a $60-\mathrm{mL}$ syringe. At each sampling depth, several void volumes were pumped before sampling. We did not purge the whole well volume for the upper beach piezometers because the permeability of the beach sand

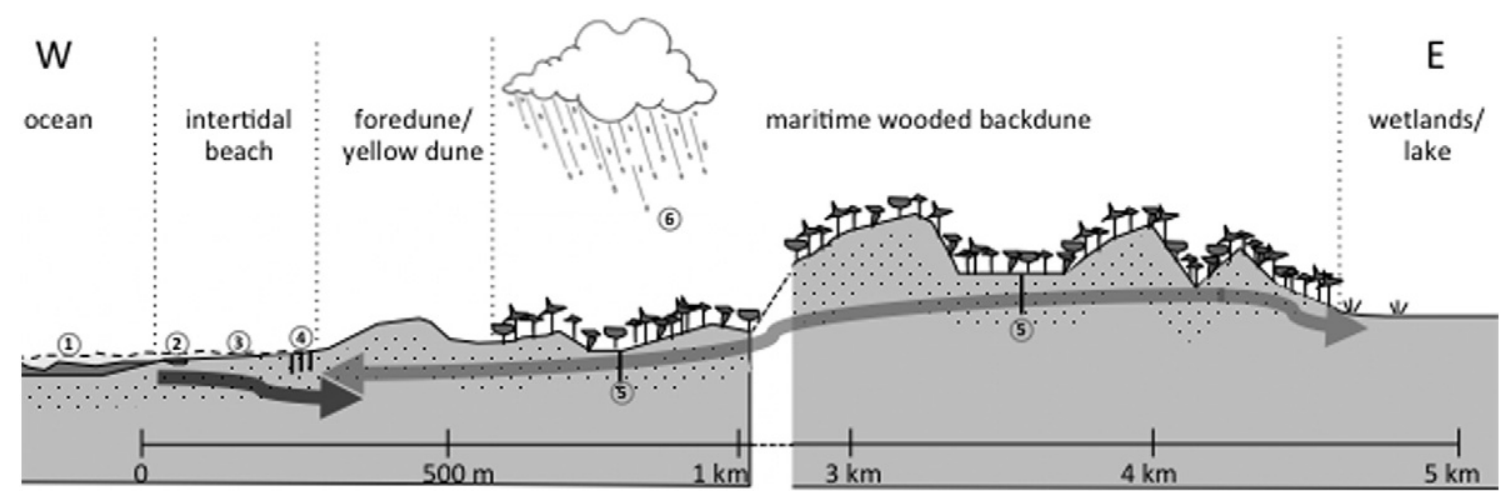

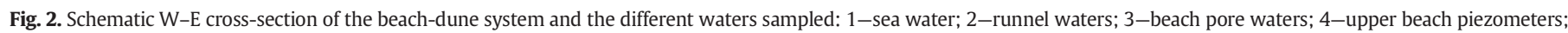
5-forest wells; 6-rainwater. 
was very high and to avoid mixing. Piezometers were mostly filled with air at low tide, and also at high tide in the case of the upper piezometer, because the water table was deep. Thus, in most cases, we sampled waters only in the deepest Tygon tubing. When we were able to sample two or three tubes per piezometer, the values were replicated, indicating that waters were homogeneous in the sampled part of the aquifer.

We also sampled waters from upland wells located behind the sand dune system in the pine forest drained directly by the beach (Fig. 2). These wells were about $10 \mathrm{~m}$ deep and were always drilled within the connected free aquifer. Waters from wells were sampled using a centrifugal pump. Waters pumped were left to overflow in a beaker while continuously measuring the conductivity, temperature, and dissolved oxygen with WTW probes. When these parameters were stabilized, samples for chemical analyses were collected using a $50 \mathrm{~mL}$ syringe. Oxygen monitoring showed that these ground waters were always anoxic. In summary, this heterogeneous sample collection allowed us to obtain several discrete samples from different places on the Aquitanian coast and a complete profile of groundwater from the forest watershed to the sandy beach at Truc Vert.

We collected 58 and 60 samples of rainwater after each precipitation event during 2008 and 2011, respectively. 2008 was the most humid year of the last $20 \mathrm{y}$, whereas 2011 was the driest, with respective precipitations at Cap Ferret of 970 and $542 \mathrm{~mm}$. The rainwater collector was located in the middle part of the studied area in the southern part of the Gironde coast (Fig. 1). The collector was an opaque polypropylene bottle fitted with a funnel. Rainwaters were collected within a few hours after rain. Three meteorological stations covering the area (Fig. 1) provided data regarding the daily amount of rainfall. We used the average of the three stations to calculate the atmospheric flux of $\mathrm{N}$ and $\mathrm{P}$.

\subsection{Analyses}

The temperature, dissolved oxygen, and salinity of water samples were immediately recorded in the waters using WTW probes or
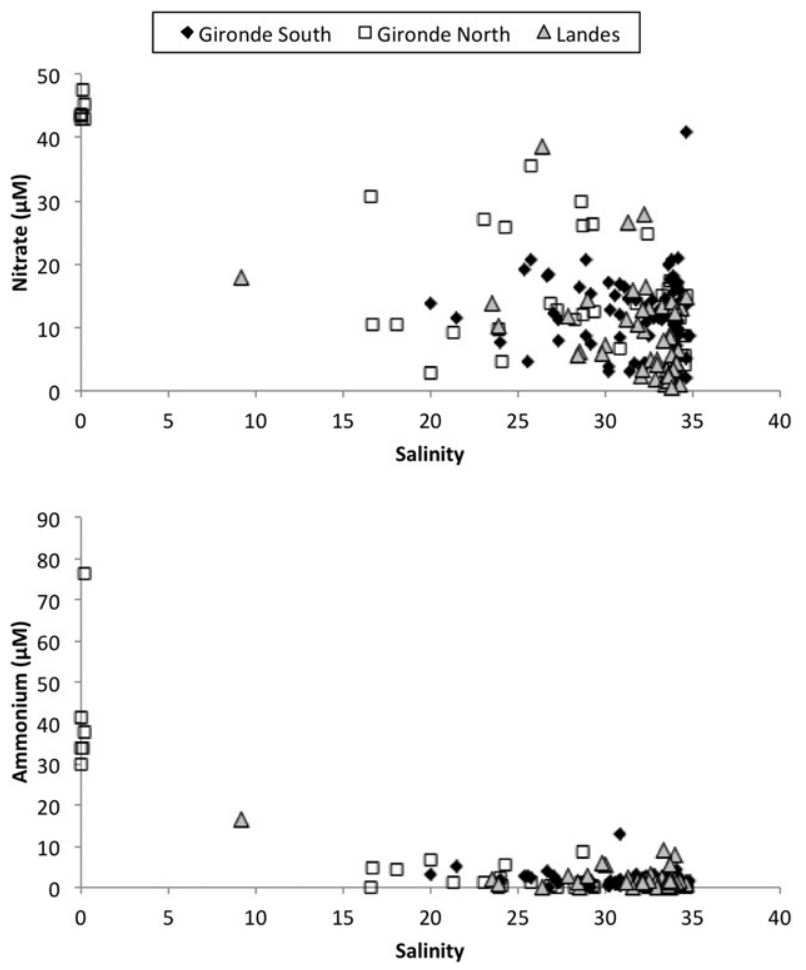

Aanderaa optodes. The probes were calibrated before and after each field campaign using an IAPSO sea water and deionized water for the salinity. Salinity probes were compensated automatically for in situ temperature. Oxygen probes were calibrated before and after each field campaign using an oxygen-free solution and an aerated solution (100\% saturation) for the oxygen saturation. Waters were filtered through a $0.45-\mu \mathrm{m}$ cellulose acetate syringe-membrane. Subsamples for dissolved inorganic phosphorus (DIP) were acidified with $\mathrm{HNO}_{3}$ to prevent scavenging by precipitation of iron oxide; two subsamples were kept frozen until later analyses of other dissolved nutrients. Dissolved nitrate and nitrite were analysed by flow injection analysis using standard methods (Anderson, 1979). The precision obtained was $\pm 10 \%$ for $\mathrm{NOx}\left(=\mathrm{NO}_{3}^{-}+\mathrm{NO}_{2}^{-}\right)$. Dissolved silica, DIP, and ammonia were analysed by colorimetric procedures (Mullin and Riley, 1955; Murphy and Riley, 1962; Strickland and Parsons, 1972). The frozen subsample was defrosted on the day of the NOx and ammonia analyses. The subsample was allowed to stand at room temperature for at least $24 \mathrm{~h}$ for depolymerization of silica before carrying out dissolved silica analysis. The obtained precision of these procedures was $\pm 5 \%$. The concentration of dissolved Fe was analysed on acidified subsamples by spectrophotometry (Stookey, 1970). Total dissolved nitrogen (TDN) concentrations were measured using the persulfate-digestion method of Valderrama (1981) to oxidize all nitrogen forms to nitrate. Dissolved organic nitrogen (DON) concentrations were calculated as TDN $\left(\mathrm{NOx}+\mathrm{NH}_{4}^{+}\right)$.

\section{Results}

\subsection{Seeping and interstitial waters of the beach}

The mean sea water temperature during sampling of Truc Vert beach was $11.0{ }^{\circ} \mathrm{C}$ in March 2013 and $19.7{ }^{\circ} \mathrm{C}$ in September 2013. The sea water salinity in the open coastal zone of the Bay of Biscay was between 34 and 36. Most of the pore waters sampled in holes dug in the beach sand and waters flowing out of the sand collected at low tide had
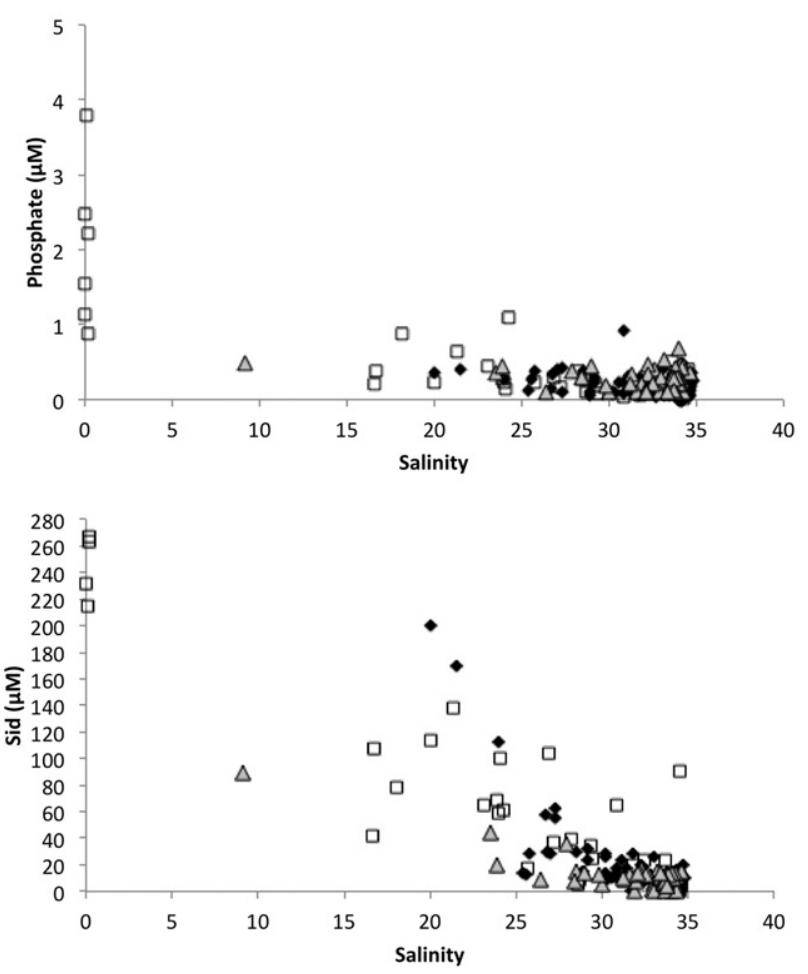

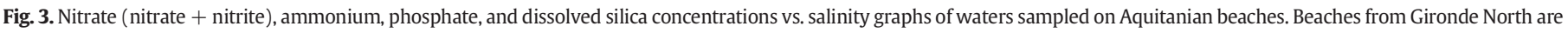

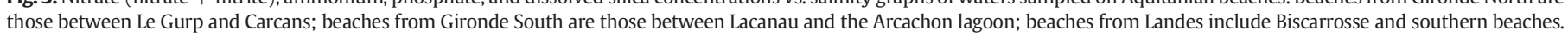
Samples with a salinity of 0 are waters seeping out the dune in north Gironde. 
salinities close to that of sea water. Nevertheless, at all locations along the Aquitanian coast, we found waters with salinities below 34 . The northern part of Gironde department was characterized by fresh water from the unconfined surficial aquifer discharging at the beach face. In the southern Gironde and in the Landes, we sampled waters with salinities down to 9, indicating that waters present in the sandy sediment of the beach were not only recirculating sea water from earlier high tides but also terrestrial groundwater mixed with sea water. Brackish waters were sampled in the lower part of the tidal beach, especially in seeping waters and in runnels isolated from the open sea water at low tide. Saline and brackish waters sampled on the beach aquifer were oxic with oxygen saturation between 50 and 100\% (Charbonnier et al., 2013a, 2013b, 2016).

Saline pore waters of the beach contained up to $40 \mu \mathrm{M}$ of NOx (Fig. 3), whereas sea water NOx concentration was always lower than $10 \mu \mathrm{M}$ (not shown on Fig. 3). Terrestrial waters seeping on the beach in the north Gironde contained between 40 and $50 \mu \mathrm{M}$ of NOx. Brackish waters had NOx concentrations between the sea water value and $40 \mu \mathrm{M}$. For a given location, a graph of NOx versus salinity generally showed a linear relationship with an extrapolated zero-salinity end-member between 40 and $50 \mu \mathrm{M}$. We observed this trend in a runnel that was isolated from sea water during $2 \mathrm{~h}$ around low tide. The salinity of the runnel water decreased with time, while the NOx concentration increased (Fig. 4), suggesting that fresh or brackish water enriched in NOx flowed in the runnel. Ammonium concentrations of sea water, saline pore waters, and brackish waters were almost always below $10 \mu \mathrm{M}$, whereas the terrestrial water end-member from north Gironde samples contained between 30 and $80 \mu \mathrm{M}$ of ammonium. DIP concentrations of sea, saline, and brackish waters collected on the beach were all below $1 \mu \mathrm{M}$, whereas the freshwater end-member had a variable DIP concentration between 1 and $4 \mu \mathrm{M}$ depending on sampling location. For DIP, as for ammonium, we noticed no linear relationship with salinity. Dissolved silica was generally below $40 \mu \mathrm{M}$ in saline waters. The concentration increased when salinity decreased. Terrestrial waters seeping in the north Gironde beaches had concentrations between 210 and $270 \mu \mathrm{M}$.

\subsection{Truc Vert subterranean estuary}

The three piezometers placed in the upper beach allowed us to sample waters from the beach aquifer in two seasons, March and September 2013. The salinity of pore waters changed according to the tidal range. One piezometer was located at the level of the high spring tide water

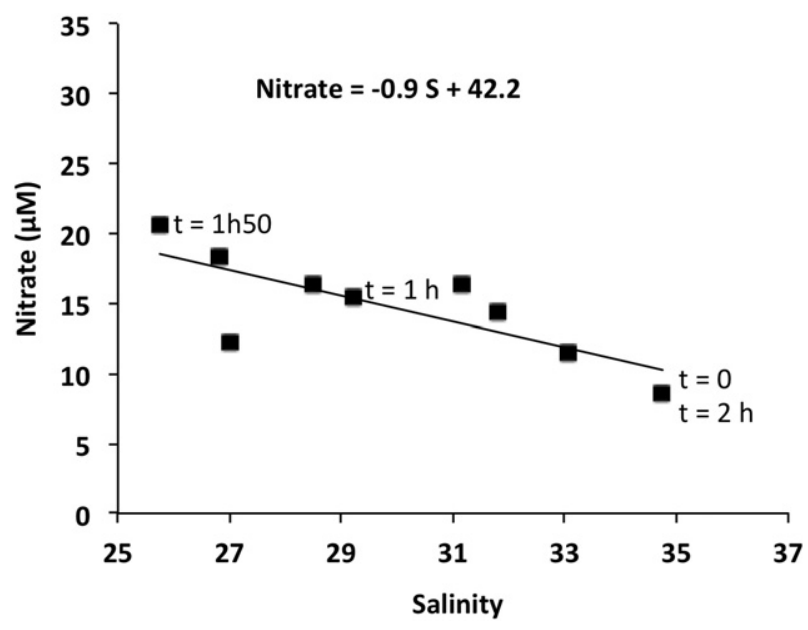

Fig. 4. Nitrate (nitrate + nitrite) and salinity of water samples collected at low tide in an isolated runnel that received seeping brackish groundwater. The runnel was isolated from seawater at $\mathrm{t}=0$ and became more and more diluted with fresh groundwater. After $2 \mathrm{~h}$, the runnel was again flooded with rising sea water. The intercept at salinity 0 corresponds to a nitrate + nitrite concentration of $42.2 \mu \mathrm{M}$. mark. It contained saline water during spring tide periods. The salinity was at 5 during neap tides. The other piezometers, located a few metres upstream, contained brackish to fresh waters with salinities lower than 15. The NOx concentration was that of sea water when pore waters were at salinity 35 . Freshwaters collected in the piezometers had a variable NOx concentration, ranging between 4 and $150 \mu \mathrm{M}$, with mean concentrations of 56.5 in March and 83.3 in September. Most of the samples with intermediate salinities had intermediate nitrate concentrations between those of the fresh and saline water end-members. The concentration of dissolved oxygen always remained above 0 in the piezometers (not shown).

Ammonium concentrations were below $2 \mu \mathrm{M}$ whatever the salinity. Only a few samples, with different salinities, showed ammonium concentrations between 2 and $8 \mu \mathrm{M}$. DON concentrations ranged from 0 to $180 \mu \mathrm{M}$. This range was close to the range of concentrations measured in sea water. DIP also showed low concentrations in saline, fresh, and intermediate water, with values below $1 \mu \mathrm{M}$. Dissolved silica had a low sea water end-member and a more concentrated and more variable freshwater end-member, like NOx. Sea water Si concentration was below $4 \mu \mathrm{M}$. Pore waters with salinities above 34 generally contained more Si than sea water, with mean concentrations of $5 \mu \mathrm{M}$ in March and $26 \mu \mathrm{M}$ in September. The freshwater end-member contained between 4 and $110 \mu \mathrm{M}$ of Si, with mean values of 20 and $55 \mu \mathrm{M}$ in March and September, respectively. Waters with intermediate salinities had intermediate Si concentrations, but the relationship between Si and salinity was not as linear as for NOx.

\subsection{Continental groundwater}

Waters collected in forest wells in uplands above the Truc Vert beach were always anoxic and contained between 13 and $240 \mu \mathrm{M}$ of dissolved iron (Fig. 5). DIN was present mostly as ammonium. Concentrations ranged between 1 and $62 \mu \mathrm{M}$ (Fig. 5). Oxidized forms of DIN were at low concentration, generally below $2 \mu \mathrm{M}$ as nitrite. Nitrate was present in two wells sampled in the forested dune anoxic aquifer in the north Gironde. DON concentrations ranged from 2 to $92 \mu \mathrm{M}$ (Fig. 5), which represented between 11 and $97 \%$ of TDN, with an average value of $63 \%$, which is very similar to that measured in several Cape Cod watersheds (Kroeger et al., 2006). DIP concentrations were high relative to the beach aquifer, with concentrations between 1 and $27 \mu \mathrm{M}$, depending on location. Except for one sample, all dune aquifer samples contained more than $220 \mu \mathrm{M}$ of dissolved Si. The highest concentrations reached $570 \mu \mathrm{M}$.

\subsection{Inorganic $N$ and $P$ contents in rainwater}

Rainwater showed variable concentrations in DIN and DIP. Both the dry and the wet years showed nitrate + nitrite and ammonium concentrations from 0 to $120 \mu \mathrm{M}$. We observed a linear relationship between NOx and ammonium, with a slope that was close to 1 (Fig. 6). The precipitation weighted averages of nitrate + nitrite were 13.4 and $17.3 \mu \mathrm{M}$ in 2008 and 2011, respectively. The values were 7.7 and $21.1 \mu \mathrm{M}$ for ammonium and 0.12 and $0.35 \mu \mathrm{M}$ for DIP. We did not observe a marked seasonal pattern in rainwater nutrient concentrations.

\section{Discussion}

\subsection{Water balance calculation}

We detected the presence of brackish waters at every point of sampling along the Aquitanian coast. Therefore, the presence of seeping terrestrial-water end-members on this coast is the rule. The choice of technique to measure the flux of terrestrial water in the environment studied is limited. The use of chemical tracers such as radium or radon isotopes (Burnett and Dulaiova, 2003; Moore, 2006) to estimate the terrestrial water flux was precluded, because in such a high-energy open 

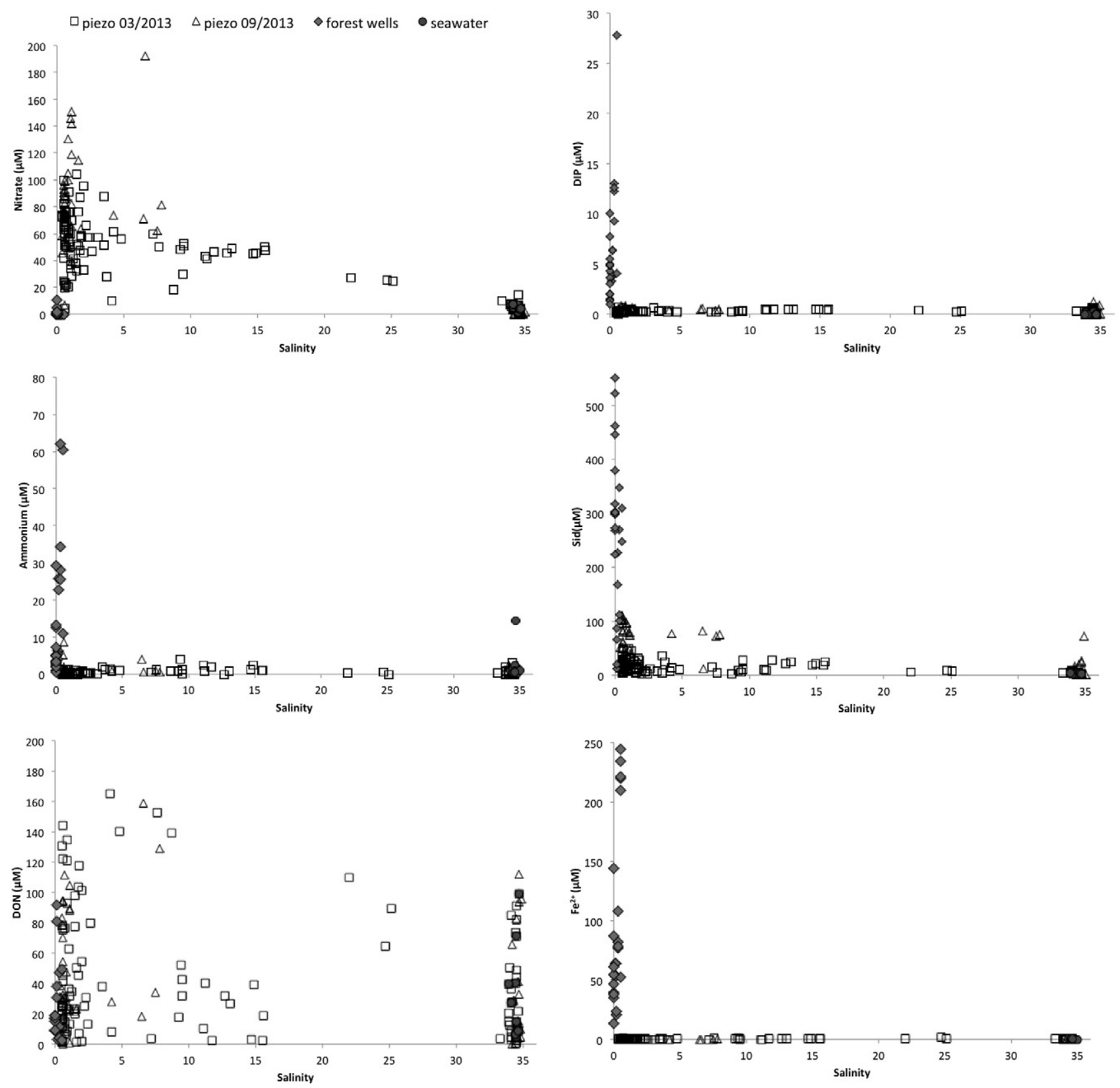

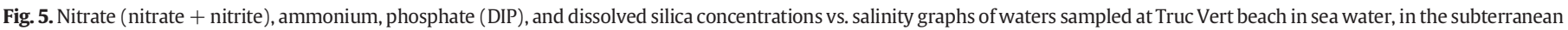
estuary (samples from upper beach piezometers collected in March 2013 and in September 2013), and in upland groundwater.

coastal system, it would be difficult to extract, from the inventory of a short-lived Ra isotope or 222Rn isotope, the parts due to terrestrial water flux and sea water recirculation due to tidal pumping (Anschutz et al., 2009; Charbonnier et al., 2013b). It would even be very difficult to estimate a radioisotope inventory because of longshore currents and swell. Salinity itself cannot be used to calculate a water mass balance, because of hydrodynamic conditions. Seepage meters are the only device that can be used to measure seepage directly. However, a serious limitation of seepage meters is the requirement that they have to be deployed in a relatively calm environment. Such devices do not operate when ambient open-water currents due to waves and tides are important (Corbett and Cable, 2003; Burnett et al., 2003). Breaking waves dislocate seepage meters and currents induce flow through the seabed when passing over and around obstacles (Huettel et al., 1996).

Another approach is the water balance calculation. This approach links the terrestrial aquifer with the beach through the discharge of groundwater, which is set by precipitation and evapotranspiration over an extended period on the catchment area that drains the coastal zone directly. The watershed of the Aquitanian coast has a surface area of $822 \mathrm{~km}^{2}$ (Fig. 1), based on hydrograph separation. This surface area excludes the catchments of sparse coastal rivers and coastal lakes. Therefore, in the considered watershed, surface runoff can be neglected in the water budget calculation since there is no river, stream, or surface drainage in the catchment, and the excess rainfall is considered to go entirely to groundwater recharge. Groundwater pumping can also be neglected, since the numerous wells that were installed in the watershed only serve for fighting potential wildfires. The mean precipitation of the studied site is $810 \mathrm{~mm} \mathrm{y}^{-1}$. Evapotranspiration from the pine forest on sand dunes represents a maximum value of $570 \mathrm{~mm} \mathrm{y}^{-1}$ (Govind et al., 2014). Thus, the hydrologic estimate of potential terrestrial groundwater recharge is at least $240 \mathrm{~mm} \mathrm{y}^{-1}$. For the whole coastal watershed, this makes approximately $200 \cdot 10^{6} \mathrm{~m}^{3} \mathrm{y}^{-1}$. At steady state, this potential recharge can be considered as the groundwater discharge. The area over which terrestrial water discharge takes place is difficult to 


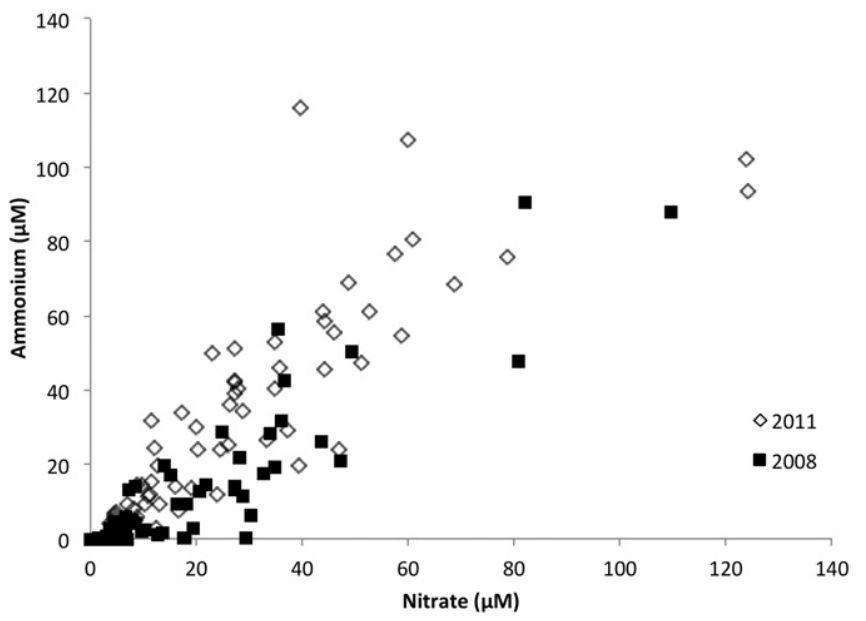

Fig. 6. Nitrate (nitrate + nitrite) vs. ammonium concentrations in rainwaters collected after every precipitation episode of years 2008 and 2011 at Biganos, close to the Arcachon lagoon.

assess because the cross-shore length where discharge occurs varies with time and space, according to beach topography and tide amplitude. Therefore we cannot represent discharge as Darcy's flux (e.g. $\mathrm{cm} \mathrm{day}^{-1}$ ). Nevertheless, we can express the groundwater discharge as the volume of water per unit length of shoreline (Sellinger, 1995; Povinec et al., 2012). Dividing this discharge rate by the $240 \mathrm{~km}$ of shoreline yields an estimated minimum discharge rate of $822 \mathrm{~m}^{3} \mathrm{y}^{-1} \mathrm{~m}^{-1}$ longshore or $2.25 \mathrm{~m}^{3} \mathrm{~d}^{-1} \mathrm{~m}^{-1}$ or $1.16 \mathrm{~m}^{3} \mathrm{~m}^{-1}$ per tide. This value is about one order of magnitude lower than the estimate based on hydrologic water balance in a Mauritius Island lagoon (Povinec et al., 2012). Our value was of the same range as that calculated from a hydrological model for the Cockburn Sound, West Australia (Smith and Nield, 2003). The difference between locations comes from the geology, geomorphology, and climate of the catchment (e.g. Taniguchi et al., 2006). In the field, we visually observed variability in groundwater seepage over distances of a few metres, despite the homogeneity of sandy sediment at this scale. Differences were probably due to a complex and moving structure of subterranean channels in the porous media. Our calculation provides a regional-scale water budget that does not take into account the detailed morphology that controls discharge at the local scale. There are uncertainties in all of the values used in the calculations. Uncertainties are low for the mean precipitation and evapotranspiration. The acquisition of additional hydrogeological data, particularly concerning the beach aquifer geometry, could be used to refine the calculation. The watershed surface area is based on hydrograph separation, which is a first estimate. But we cannot do better for now. The estimate of the groundwater flow is unlikely to increase but could decrease if the aquifer directly connected to the beach is smaller than estimated.

The value of the terrestrial groundwater flow could be independently checked by performing a calculation using Darcy's law or a numerical hydrological model. The use of a hydrological model based on aquifer properties (permeability, hydraulic conductivity) and data on freshwater head and hydraulic gradient is a good way to assess the terrestrial water flow. However, this approach in coastal zones necessitates several simplifying assumptions related to the effect of water head change (Spiteri et al., 2008). Our studied site is not simple, and simplification of models would be needed because several parameters are not available. Hydrodynamic conditions are rough, which prevents the installation of piezometers in the intertidal beach section. The presence of protected high aeolian sand dunes also prevents the installation of piezometers to obtain data on water head close to the beach. Therefore, we have data on the freshwater head only beyond the dune, that is, several hundred metres from the beach, while there is probably a variable hydraulic gradient between the forested dune, the foredune, and the beach. So, data on the geometry of the studied aquifer and its evolution with seasons are not available for our site and results from a numerical model would be tainted by an inaccuracy greater than the water balance approach we used.

\subsection{Nutrient fluxes}

Simply multiplying the average nutrient concentration in continental groundwater by the terrestrial submarine water discharge rate will lead to accurate fluxes only for conservative species. However, nutrients are not conservative species. Additional processes can add or remove $\mathrm{N}$, $\mathrm{P}$, and $\mathrm{Si}$ species at the boundary between fresh and saline waters and in the tidal beach zone.

Filtration of sea water through sandy sediments of exposed beaches supplies oxygen and marine organic matter in permeable tidal sediments (Riedl and Machan, 1972; Rauch and Denis, 2008; Rocha, 2008; Dugan et al., 2011). The mineralization of this organic matter represents a source of nutrients to the shallow coastal zone (Avery et al., 2008). This process has been studied at Truc Vert beach (Anschutz et al., 2009; Charbonnier et al., 2013a). It has been shown that about $2.5 \mathrm{~km}^{3}$ of sea water is filtered each year in the sand by tidal pumping along the 240-km-long Aquitanian beach. As a consequence, $44 \cdot 10^{6} \mathrm{~mol}$ of NOx are released each year to the adjacent coastal zone by this process. The intra-beach recycling of marine nitrogen explains the large range of NOx concentrations observed in samples with sea water salinities (Fig. 3). The samples with high NOx concentrations also represent waters depleted in dissolved oxygen due to aerobic respiration (Charbonnier et al., 2013a). These samples are also enriched in dissolved silica due to quartz dissolution. Actually, silica concentrations remain far below saturation level with respect to quartz, and pore waters remain in the beach aquifer for several days (Anschutz et al., 2009). This enrichment was higher in September than in March, probably because sea water was warmer, which would enhance the quartz dissolution kinetics (Dove, 1994; Anschutz et al., 2009). Saline pore waters are not enriched in DIP relative to sea water, probably because DIP released from organic matter mineralization remains adsorbed on sediment particles.

Terrestrial groundwater constitutes an additional source of nutrients for the coastal ocean (Bowen et al., 2007). In the present study, we have sampled brackish pore waters in the seepage zone and in piezometers located in the upper Truc Vert beach. They reveal that the terrestrial groundwater end-member is enriched in nutrients (Fig. 5). We have collected three kinds of freshwaters with different nutrient concentrations: first, anoxic waters from wells located in the forested dune, second, oxic freshwaters from the upper beach piezometers, and third, fresh water seeping directly out of the dune in the north Gironde. Truc Vert upland wells contained DIN concentrations up to $62 \mu \mathrm{M}$, mostly as ammonium, whereas upper beach freshwaters were depleted in ammonium but enriched in NOx up to $150 \mu \mathrm{M}$. Seeping waters from the north Gironde were intermediate, with both NOx and ammonium. This suggests that nitrification of ammonium occurred as in other subterranean estuaries (Spiteri et al., 2008; Anwar et al., 2014). At our study site, however, the redox front did not correspond to the salinity gradient, because the transformation of ammonium in NOx occurred in freshwaters. This may be linked to the presence of a foredune depleted in organic soil. At the station where we collected seeping freshwaters (Gurp beach), the foredune was reduced, whereas it was up to $200 \mathrm{~m}$ wide at Truc Vert beach. In this part of the catchment, which is directly connected to the beach aquifer, rainwater percolates in sand with few biogeochemical transformations. The redox front most likely occurs where upland groundwater meets dune groundwater. Piezometers installed between foredunes and the end of wooded backdunes would allow us to better characterize the groundwater redox boundary.

The large range of nitrate + nitrite concentrations in the upper beach freshwaters could reflect variable concentrations of DIN in rainwaters and in the aquifer (e.g. Bowen et al., 2007). One major 
biogeochemical transformation of rainwater in the foredune aquifer is the nitrification of ammonium, since dissolved ammonium is at very low concentrations in the upper beach aquifer, whereas it is as concentrated as NOx in rainwaters (Fig. 6). This process may be favoured by nitrifying bacteria present in the sandy sediment. This process consumes dissolved oxygen with a stoichiometric ratio of two $\mathrm{O}_{2}$ for one ammonium nitrified to NOx. Considering the weighted average ammonium concentration of $21.1 \mu \mathrm{M}$, which was the high value in 2011 , nitrification would consume $42.2 \mu \mathrm{M}$ of dissolved $\mathrm{O}_{2}$, which is not enough to shift rainwater to anoxia. Ammonium may also be adsorbed on particles during passage through sediments. Sorption by cation exchange reactions at negatively charged clay mineral surfaces may control ammonium migration in aquifers (Buss et al., 2004; Lorah et al., 2009). The cationic exchange capacity reported for sands sampled in the same geological setting is close to $1 \mathrm{meq} 100 \mathrm{~g}^{-1}$ (Canton et al., 2010). This value is low, but may support a partial retention of ammonium.

Since nitrification of ammonium occurs in the terrestrial freshwater aquifer, the concentration of NOx in the salinity range of 1-35 is approximately conservative between low concentrations at salinity 35 and a mean concentration of about $40-50 \mu \mathrm{M}$ in the terrestrial water endmember (Figs. 4 and 5). This end-member has been measured at Truc Vert beach and in other places on the Aquitanian coast (Fig. 2), suggesting that it is relatively constant. Nitrate + nitrite is nearly ubiquitous in oxic groundwater and travels through aquifers with minimal physical retention (Capone and Bautista, 1985). Therefore an up-scaling of the DIN flux from terrestrial groundwater discharge can be assessed. Considering a mean DIN concentration of $45 \mu \mathrm{M}$ for the terrestrial water end-member and a minimum annual groundwater flux of $200 \cdot 10^{6} \mathrm{~m}^{3} \mathrm{y}^{-1}$, we obtain a DIN flux from terrestrial SGD of $9 \cdot 10^{6} \mathrm{~mol}$ (126 tonnes) each year to the adjacent coastal zone. This flux is lower than the release of DIN due to tidally driven recycled sea water, which results from the recycling of a mean concentration of $17.4 \cdot \mathrm{M}$ of DIN in $2500 \cdot 10^{6} \mathrm{~m}^{3} \mathrm{y}^{-1}$ of recirculating sea water (i.e. 600 tonnes of DIN $y^{-1}$, Charbonnier et al., 2013a). It is much lower than the mean flux of DIN coming from the rivers of the Aquitanian coast $(>30,000 t)$, because the surface of the beach catchment is much lower than river catchments. Nevertheless, the SGD flux contributes to a diffuse input of available and new DIN to the marine environment all along the coastal zone, which could impact the microbial community (Garcés et al., 2011).

Dissolved organic nitrogen concentrations ranged from 0 to $100 \mu \mathrm{M}$ in both terrestrial freshwaters and sea water. DON concentrations in the salinity gradient are between both end-members, except some samples in the $0-10$ salinity interval, which are enriched in DON, like DIN, suggesting additional input of DON in the redox front. DON, which represents a mean proportion of $63 \%$ of TDN in the terrestrial end-member, is the dominant form of $\mathrm{N}$ exported to the coastal zone (Kroeger et al., 2006). The direct impact of DON export from terrestrial SGD on coastal water biogeochemistry depends on the bioavailability and/or mineralization of DON, which can be low in coastal zones (Seitzinger et al., 2002; Agedah et al., 2009).

Dissolved phosphate concentrations were between 1 and $27 \mu \mathrm{M}$ in the forested dune aquifer. They were also above $1 \mu \mathrm{M}$ where freshwaters seeped directly on the beach (north Gironde). They were below $1 \mu \mathrm{M}$ in freshwaters collected in Truc Vert beach piezometers. Freshwaters enriched in DIP were anoxic and contained dissolved iron. Dissolved iron is probably oxidized at the redox front in the foredune aquifer, where ammonium is nitrified. As a result, authigenic iron oxides may trap DIP by an adsorption process. The so-called "iron curtain" (Charette and Sholkovitz, 2002; Spiteri et al., 2008) leads to the removal of phosphate. This process consumes dissolved oxygen with a stoichiometric ratio of one $\mathrm{O}_{2}$ to four $\mathrm{Fe}(\mathrm{II})$ oxidized to $\mathrm{Fe}(\mathrm{III})$-oxide. Considering the maximum $\mathrm{Fe}$ (II) concentration of $240 \mu \mathrm{M}$ measured in upland wells, iron oxidation would consume $60 \mu \mathrm{M}$ of dissolved $\mathrm{O}_{2}$, which is not enough to shift $\mathrm{O}_{2}$-saturated freshwaters to anoxia at the redox front.
At the redox front, the efficiency of the process of phosphate removal depends on the Fe(II)/DIP ratio (Griffoen, 1994). Anschutz et al. (2007) showed that phosphate was quantitatively adsorbed when the ratio exceeded 5. In our case, the Fe(II)/DIP ratio in forest aquifer was above 6 and up to 40 , except in one single well, where the mean value was 3.5. Therefore, DIP was potentially totally adsorbed on iron oxides. As a consequence, terrestrial groundwater was not a source of phosphate for the coastal ocean. This also implies that a large quantity of $\mathrm{P}$ is trapped at the present-day redox boundary. The shifting of this boundary for any reason, such as sea level rise, upland groundwater use, or erosion of the bare foredune, would cause a release of $P$ through reductive dissolution of Fe-oxides. The direct seepage on the beach of ironand DIP-rich freshwaters in the north Gironde is probably a consequence of dune erosion, which is known to occur there (Aubie and Tastet, 2000).

Dissolved silica in upland wells was far above supersaturation with respect to quartz. At the maximal temperature measured in wells $\left(16{ }^{\circ} \mathrm{C}\right.$ ), the quartz solubility was $138 \mu \mathrm{M}$ of $\mathrm{H}_{4} \mathrm{SiO}_{4}$ (Gunnarsson and Arnorsson, 2000). On the other hand, Si concentrations were below the solubility of amorphous silica, which was at $1600 \mu \mathrm{M}$. Therefore the concentration of $\mathrm{Si}$ in groundwater did not result from the dissolution of the quartz-bearing aquifer but most likely from phytoliths released from the breakdown of plant organic matter (Gerard et al., 2008). The dissolved silica concentration measured in fresh water from the Truc Vert beach piezometers was below the value measured in the upland aquifer end-member. A part of the missing Si may have co-precipitated with iron oxides. However, the missing Si was above the concentration of dissolved $\mathrm{Fe}(\mathrm{II})$ in groundwater, suggesting that the co-precipitation process was not the dominant process of Si removal. Here, upland aquifer freshwater was most likely partly diluted with foredune pore waters that were not enriched in Si from biogenic amorphous silica dissolution.

\section{Conclusions}

According to Zektser and Loaiciga (1993), only approximately 2\% of global precipitation is channelled into direct groundwater discharge to the ocean. The beach catchment studied here represents less than $1 \%$ of the watershed of the large rivers of southwest France (Dordogne, Garonne, Leyre, Adour; Fig. 1) that flow into the Bay of Biscay. The contribution of terrestrial SGD based on the water balance approach also represents less than $1 \%$ of the regional water budget. The nitrate + nitrite concentration of the upper beach freshwater endmember is lower than that of the above mentioned rivers. Therefore, terrestrial SGD may not rival river input in the studied region. One reason for the low DIN flux from SGD is the land use, which consists almost exclusively of forested and bare sand dunes. It is likely that land uses that are more detrimental for water quality, such as agriculture or waste water infiltration, would have a higher impact on DIN fluxes from SGD (Slomp and Van Cappellen, 2004; Kroeger et al., 2006; Canton et al., 2010). Treated waste water infiltration plants have been recently implemented in the forested sand dune aquifer close to the small villages situated upland. The DIN concentration of SGD located on beaches downstream of these plants should be monitored to follow their possible impact on nutrient input to the coast. Nevertheless, terrestrial SGD is a net source of NOx all along the sandy Aquitanian coast. This makes an additional source of NOx to the one originating from sea water circulation in the tidal beach zone (Charbonnier et al., 2013a). Both sources increase the N/P ratio of available nutrients.

The subterranean estuary studied here, that is, the subterranean salinity front, is not a redox front. Terrestrial groundwater of the surficial aquifer of the upland forested dune is anoxic. Freshwaters from the unconfined upper beach surficial aquifer are oxic: the redox front occurs upstream of the saline front, below the foredune depleted in organic soil. Groundwater ammonium is nitrified and phosphate is trapped on iron oxides that precipitate at this redox boundary. 


\section{Acknowledgements}

The authors gratefully acknowledge several colleagues and students who helped us at the study site during the different field experiments (Thomas Smith, Marie Wawrzykowski, Sandrine Cassous-Ribehart, Mathilde Leymarie, Mathieu Canton, Stéphane Bujan). The French National Programs EC2CO-MOBISEA and ESTAFET (CNRS-INSU) and the ANR-06-BLAN PROTIDAL funded this study. This study has been carried out in the frame of the Investments for the future Program, within the Cluster of Excellence COTE (ANR-10-LABEX-45).

\section{References}

Agedah, E.C., Binalaiyifa, H.E., Ball, A.S., Nedwell, D.B., 2009. Sources, turnover and bioavailability of dissolved organic nitrogen (DON) in the Colne estuary, UK. Mar. Ecol. Prog. Ser. 382, 23-33.

Anderson, L., 1979. Simultaneous spectrophotometric determination of nitrite and nitrate by flow injection analysis. Anal. Chim. Acta 110, 123-128.

Anschutz, P., Chaillou, G., Lecroart, P., 2007. Phosphorus diagenesis in the sediment of the Thau Lagoon. Estuar. Coast. Shelf Sci. 72, 447-456.

Anschutz, P., Smith, T., Mouret, A., Deborde, J., Bujan, S., Poirier, P., Lecroart, P., 2009. Tidal sands as biogeochemical reactors. Estuar. Coast. Shelf Sci. 84, 84-90.

Anwar, N., Robinson, C., Barry, D.A., 2014. Influence of tides and waves on the fate of nutrients in a nearshore aquifer: numerical simulations. Adv. Water Resour. 73, 203-213.

Aubie, S., Tastet, J.-P., 2000. Coastal erosion, processes and rates: an historical study of the Gironde coastline, southwestern France. J. Coast. Res. 16 (3), 756-767.

Avery Jr., G.B., Kieber, R.J., Taylor, K.J., 2008. Nitrogen release from surface sand of a high energy beach along the southeastern coast of North Carolina, USA. Biogeochemistry 89 (3), 357-365

Banks, W., Paylor, R., Hughes, W., 1996. Using thermal infrared imagery to delineate groundwater discharge. Groundwater 34, 434-443.

Berner, E.K., Berner, R.A., 1987. The Global Water Cycle. Prentice-Hall, Englewood Cliffs, NJ.

Billerbeck, M., Werner, U., Bosselmann, K., Walpersdorf, E., Huettel, M., 2006. Nutrient release from an exposed intertidal sand flat. Mar. Ecol. Prog. Ser. 316, 35-51.

Bosch, J.M., Hewlett, J.D., 1982. A review of catchment experiments to determine the effect of vegetation changes on water yield and evapotranspiration. J. Hydrol. 55, 3-23.

Bowen, J.L., Kroeger, K.D., Tomasky, G., Pabich, W.J., Cole, M.L., Carmichael, R.H., Valiela, I., 2007. A review of land-sea coupling by groundwater discharge of nitrogen to New England estuaries: mechanisms and effects. Appl. Geochem. 22, 175-191.

Burnett, W.C., Dulaiova, H., 2003. Estimating the dynamics of groundwater input into the coastal zone via continuous radon-222 measurements. J. Environ. Radioact. 69, $21-35$.

Burnett, W.C., Bokuniewicz, H., Huettel, M., Moore, W.S., Taniguchi, M., 2003. Groundwater and pore water inputs to the coastal zone. Biogeochemistry 66, 3-33.

Burnett, W.C., Aggarwal, P.K., Aureli, A., Bokuniewicz, H., Cable, J.E., Charette, M.A., Kontar, E., Krupa, S., Kulkarni, K.M., Loveless, A., Moore, W.S., Oberdorfer, J.A., Oliveira, J., Ozyurt, N., Povinec, P., Privitera, A.M.G., Rajar, R., Ramessur, R.T., Scholten, J. Stieglitz, T., Tanigushi, M., Turner, J.V., 2006. Quantifying submarine groundwater discharge in the coastal zone via multiple methods. Sci. Total Environ. 367, 498-543.

Buss, S.R., Herbert, A.W., Morgan, P., Thornton, S.F., Smith, J.W.N., 2004. A review of ammonium attenuation in soil and groundwater. Q. J. Eng. Geol. Hydrogeol. 37 (4), 347-359.

Butel, R., Dupuis, H., Bonneton, P., 2002. Spatial variability of waves conditions on the French Aquitanian coast using in-situ data. J. Coast. Res. 36, 96-108.

Canton, M., Anschutz, P., Naudet, V., Molnar, N., Mouret, A., Francecshi, M., Naessens, F., Poirier, D., 2010. Impact of a solid waste disposal on nutrient dynamics in a sandy catchment. J. Contam. Hydrol. 116, 1-15.

Canton, M., Anschutz, P., Coynel, A., Polsenaere, P., Auby, I., Poirier, D., 2012. Nutrient export to an Eastern Atlantic coastal zone: first modeling and nitrogen mass balance. Biogeochemistry 107, 361-377.

Capone, D.G., Bautista, M.F., 1985. A groundwater source of nitrate in nearshore marine sediments. Nature 313, 214-216

Castelle, B., Bonneton, P., Dupuis, H., Sénéchal, N., 2007. Double bar beach dynamics on the high-energy meso-macrotidal French Aquitanian Coast: a review. Mar. Geol. $245,141-159$.

Charbonnier, C., Anschutz, P., Poirier, D., Bujan, S., Lecroart, P., 2013a. Aerobic respiration in a high-energy sandy beach. Mar. Chem. 155, 10-21.

Charbonnier, C., Anschutz, P., Deflandre, B., Poirier, D., Bujan, S., Lecroart, P., 2013b. Influence of physical forcing on pore water properties of a tidal sandy beach (TrucVert, Aquitaine, France). Coast. Dynamics 33.

Charbonnier, C., Anschutz, P., Deflandre, B., Poirier, D., Bujan, S., Lecroart, P., 2016. Measuring pore water oxygen of a high-energy beach using buried probes. Estuar. Coast. Shelf Sci. http://dx.doi.org/10.1016/j.ecss.2015.12.004.

Charette, M.A., Sholkovitz, E.R., 2002. Oxidative precipitation of groundwater-derived ferrous iron in the subterranean estuary of a coastal bay. Geophys. Res. Lett. 29, 1444-1447.

Charette, M.A., Buesseler, K.O., Andrews, J.E., 2001. Utility of radium isotopes for evaluating the input and transport of groundwater-derived nitrogen to a Cape Cod estuary. Limnol. Oceanogr. 46, 465-470.
Corbett, D.R., Cable, J.E., 2003. Seepage meters and advective transport in coastal environments: comments on "seepage meters and Bernoulli's revenge" by E.A. Shinn, C.D. Reich, and T.D. Hickey. Estuaries 26 (5), 1383-1389.

Deborde, J., Anschutz, P., Auby, I., Glé, C., Commarieu, M.V., Maurer, D., Lecroart, P., Abril, G., 2008. Role of tidal pumping on nutrient cycling in a temperate lagoon (Arcachon Bay, France). Mar. Chem. 109 (1-2), 98-114.

Dove, P.M., 1994. The dissolution kinetics of quartz in sodium chloride solutions at $25^{\circ} \mathrm{C}$ to $300{ }^{\circ} \mathrm{C}$. Am. J. Sci. 294, 665-712.

Dugan, J.E., Hubbard, D.M., Page, H.M., Schimel, J.P., 2011. Marine macrophyte wrack inputs and dissolved nutrients in beach sands. Estuar. Coasts 34 (4), 839-850.

Fischer, W.A., Moxham, R.M., Polcyn, F., Landis, G.H., 1964. Infrared surveys of Hawaiian volcanoes. Science 146, 733-742.

Garcés, E., Basterretxea, G., Tovar-Sánchez, A., 2011. Changes in microbial communities in response to submarine groundwater input. Mar. Ecol. Prog. Ser. 438, 47-58.

Garrels, R.M., MacKenzie, F.T., 1971. Evolution of Sedimentary Rocks. Norton and Co., New York, p. 397 pp.

Gerard, F., Mayer, K.U., Hodson, M.J., Ranger, J., 2008. Modeling the biogeochemical cycle of silicon in soils: application to a temperate forest ecosystem. Geochim. Cosmochim. Acta 72, 741-758.

Govind, A., Cowling, S., Kumari, J., Rajan, N., Al-Yaari, A., 2014. Distributed modeling of ecohydrological processes at high spatial resolution over a landscape having patches of managed forest stands and crop fields in SW Europe. Ecol. Model. 297, 126-140.

Griffoen, J., 1994. Uptake of phosphate by iron hydroxides during seepage in relation to development of groundwater composition in coastal areas. Environ. Sci. Technol. 28, 675-681.

Gunnarsson, I., Arnorsson, S., 2000. Amorphous silica solubility and the thermodynamic properties of $\mathrm{H}_{4} \mathrm{SiO}_{4}$ in the range of $0^{\circ}$ to $350{ }^{\circ} \mathrm{C}$ at Psat. Geochim. Cosmochim. Acta 64 (13), 2295-2307.

Huettel, M., Ziebis, W., Forster, S., 1996. Flow-induced uptake of particulate matter in permeable sediments. Limnol. Oceanogr. 41 (2), 309-322.

Knee, K.L., Paytan, A., 2011. Submarine groundwater discharge: a source of nutrients metals and pollutants to the coastal ocean. In: Wolanski, E., Mclusky, D.S. (Eds.), Treatise on Estuarine and Coastal Science. 4, pp. 205-233.

Kroeger, K.D., Charette, M.A., 2008. Nitrogen biogeochemistry of submarine groundwater discharge. Limnol. Oceanogr. 53 (3), 1025-1039.

Kroeger, K.D., Cole, M.L., Valiela, I., 2006. Controls on groundwater-transported dissolved organic nitrogen and nitrate yields from coastal watersheds. Limnol. Oceanogr. 51, 2248-2261

Kwon, E.Y., Kim, G., Primeau, F., Moore, W.S., Cho, H., Devries, T., Sarmiento, J.L., Charette M.A., Cho, Y., 2014. Global estimate of submarine groundwater discharge based on an observationally constrained radium isotope model. Geophys. Res. Lett. 41 (23) 8438-8444. http://dx.doi.org/10.1002/2014GL061574.

Lee, Y.-W., Kim, G., Lim, W.A., Hwang, D.W. 2010. A relationship between submarine groundwater-borne nutrients traced by Ra isotopes and the intensity of dinoflagellate red-tides occurring in the southern sea of Korea. Limnol. Oceanogr. 55, 1-10.

Legigan, P., 1979. L'élaboration de la formation du sable des Landes, dépot résiduel de l'environnement sédimentaire pliocène-pléistocène centre aquitain. Thesis. Université de Bordeaux, Bordeaux, p. 429 pp.

Lévêque, P.C., Gros, J.-C., Maurin, C., Sévérac, J., Siméon, C., Viguier, C., 1972. Utilisation de la télédétection infrarouge et des mesures isotopiques - tritium et oxygène 18- pour l'étude des résurgences d'eau le long du littoral aquitain. C. R. Acad. Sci. Paris 274, 2841-2844.

Lorah, M.M., Cozzarelli, I.M., Böhlke, J.K., 2009. Biogeochemistry at a wetland sedimentalluvial aquifer interface in a landfill leachate plume. J. Contam. Hydrol. 105 (3-4), 99-117.

Loveless, A.M., Oldham, C.E., 2010. Natural attenuation of nitrogen in groundwate discharging through a sandy beach. Biogeochemistry 98 (1-3), 75-87.

McLachlan, A., Brown, A.C., 2006. The Ecology of Sandy Shores. Academic Press, Burlington, Massachusetts.

Michael, H.A., Lubetsky, J.S., Harvey, C.F., 2003. Characterizing submarine groundwater discharge: a seepage meter study in Waquoit Bay, Massachusetts. Geophys. Res. Lett. 30 (6), 1297.

Michel, D., Howa, H., 1999. Short-term morphodynamic response of a ridge and runnel system on a mesotidal sandy beach. J. Coast. Res. 15, 428-437.

Moore, W.S., 2006. The role of submarine groundwater discharge in coastal biogeochemistry. J. Geochem. Explor. 88 (1-3), 389-393.

Moore, W.S., 2010. The effect of submarine groundwater discharge on the ocean. Ann. Rev. Mar. Sci. 2 (1), 59-88.

Mullin, J.B., Riley, J.P., 1955. The spectrophotometric determination of silicate-silicon in natural waters with special reference to sea water. Anal. Chem. Acta 12, 162-170.

Murphy, J., Riley, J.P., 1962. A modified single solution method for determination of phosphate in natural waters. Anal. Chim. Acta 42, 31-36.

Pitaud, G., 1967. L'hydrogéologie et la végétation dans les dunes du littoral aquitain. Thesis, University Bordeaux no. 460149 pp.

Povinec, P.P., Burnett, W.C., Beck, A., Bokuniewicz, H., Charette, M.A., Gonneea, M.E., Groening, M., Ishitobi, T., Kontar, E., Liong Wee Kwong, L., Marie, D.E.P., Moore, W.S., Oberdorfer, J.A., Peterson, R., Ramessur, R., Rapaglia, J., Stieglitz, T., Top, Z. 2012. Isotopic, geophysical and biogeochemical investigation of submarine groundwater discharge: IAEA-UNESCO intercomparison exercise at Mauritius island. J. Environ. Radioact. 104 (1), 24-45.

Rauch, M., Denis, L., 2008. Spatio-temporal variability in benthic mineralization processes in the eastern English Channel. Biogeochemistry 89, 163-180.

Riedl, R.J., Machan, R., 1972. Hydrodynamic patterns in lotic intertidal sands and their bioclimatological implications. Mar. Biol. 13, 179-209.

Rocha, C., 2008. Sandy sediments as active biogeochemical reactors: compounds cycling in the fast lane. Aquat. Microb. Ecol. 53, 119-127. 
Roxburgh, I.S., 1985. Thermal infrared detection of submarine spring associated with the Plymouth Limestone. Hydrol. Sci. J. 30, 185-196.

Santos, I.R., Burnett, W.C., Chanton, J., Mwashote, B., Suryaputra, I.G.N.A., Dittmar, T., 2008 Nutrient biogeochemistry in a Gulf of Mexico subterranean estuary and groundwater-derived fluxes to the coastal ocean. Limnol. Oceanogr. 53 (2), 705-718.

Seitzinger, S.P., Sanders, R.W., Styles, R., 2002. Bio-availability of DON from natural and anthropogenic sources to estuarine plankton. Limnol. Oceanogr. 47, 353-366.

Sellinger, C.E., 1995. Groundwater flux into a portion of eastern Lake Michigan. J. Great Lakes Res. 21, 53-63.

Short, A.D., 1991. Macro-meso tidal beach morphodynamics- an overview. J. Coast. Res. 7, 417-436.

Short, A.D., Aagaard, T., 1993. Single- and multi-bar beach change models. J.Coast. Res. SI15 141-157.

Slomp, C.P., Van Cappellen, P., 2004. Nutrients inputs to the coastal ocean through submarine groundwater discharge: controls and potential impact. J. Hydrol. 295, 64-86.

Smith, A.J., Nield, S.P., 2003. Groundwater discharge from the superficial aquifer into Cockburn Sound Western Australia: estimation by inshore water balance. Biogeochemistry 66, 125-144.

Spiteri, C., Slomp, C.P., Tuncay, K., Meile, C., 2008. Modeling biogeochemical processes in subterranean estuaries: effect of flow dynamics and redox conditions on submarine groundwater discharge of nutrients. Water Resour. Res. 44 (2), 1-18.

Stookey, L.L., 1970. Ferrozine-a new spectrophotometric reagent for iron. Analytica Anal. Chem. Acta 42, 779-781.
Strickland, J.D.H., Parsons, T.R., 1972. A practical handbook of sea water analysis. Fish. Res. Board Can. Bull. 167, 1-31.

Taniguchi, M., Fukuo, Y., 1993. Continuous measurements of groundwater seepage using an automated seepage meter. Ground Water 31, 675-679.

Taniguchi, M., Burnett, W.C., Dulaiova, H., Kontar, E.A., Povinec, P.P., Moore, W.S., 2006. Submarine groundwater discharge measured by seepage meters in Sicilian coastal waters. Cont. Shelf Res. 26, 835-842.

Ullman, W.J., Chang, B., Miller, D.C., Madsen, J.A., 2003. Groundwater mixing, nutrient diagenesis, and discharges across a sandy beachface, Cape Henlopen, Delaware (USA). Estuar. Coast. Shelf Sci. 57, 539-552.

Valderrama, J.C., 1981. The simultaneous analysis of total nitrogen and total phosphorus in natural waters. Mar. Chem. 10, 109-122.

Vertessy, R.A., Zhang, L., Dawes, W.R., 2003. Plantations, river flows and river salinity. Aust. For. 66, 55-61.

Zektser, I.S., Loaiciga, H.A., 1993. Groundwater fluxes in the global hydrologic cycle: past, present, and future. J. Hydrol. 144, 405-427.

Zimmermann, C.F., Montgomery, J.R., Carlson, P.R., 1985. Variability of dissolved reactive phosphate flux rates in nearshore estuarine sediments: effects of groundwater flow. Estuaries 8 (2), 228-236. 